\title{
Symbols of power: the Silchester bronze eagle and eagles in Roman Britain
}

Article

Accepted Version

Durham, E. (2013) Symbols of power: the Silchester bronze eagle and eagles in Roman Britain. Archaeological Journal, 170 (1). pp. 78-105. ISSN 0066-5983 doi:

https://doi.org/10.1080/00665983.2013.11021002 Available at https://centaur.reading.ac.uk/39195/

It is advisable to refer to the publisher's version if you intend to cite from the work. See Guidance on citing.

To link to this article DOI: http://dx.doi.org/10.1080/00665983.2013.11021002

Publisher: Royal Archaeological Institute

All outputs in CentAUR are protected by Intellectual Property Rights law, including copyright law. Copyright and IPR is retained by the creators or other copyright holders. Terms and conditions for use of this material are defined in the End User Agreement.

\section{www.reading.ac.uk/centaur}

\section{CentAUR}

Central Archive at the University of Reading

Reading's research outputs online 


\section{Author's Original Manuscript - Postprint}

This is an Author's Accepted Manuscript of an article published as: Durham, E. 2014. 'Symbols of power: the Silchester bronze eagle and eagles in Roman Britain', Archaeological Journal 170 (2013), 78-105

Routledge (Taylor \& Francis), available online at:

http://www.tandfonline.com/toc/raij20/current\#.VKKuR14gAA.

\section{Symbols of power: the Silchester bronze eagle and eagles in Roman Britain}

Emma Durham with a contribution by Michael Fulford

Those who study Roman art and religion in Britain will know that there are a relatively small number of pieces in stone and bronze which are regularly used to illustrate arguments on Romanization, provincialism and identity. However, while these objects become familiar through such use, they are, in fact, often little studied as pieces in their own right and the only description of their appearance and context are some fifty or more years old. Reexcavation of the context from which the Silchester eagle was recovered has raised questions about the date of its deposition, as well as its origin and use, and indeed the nature of its deposition at Silchester. This paper examines the figurine in detail, the role of the eagle at Silchester and explores the significance of the eagle more widely in Roman Britain.

\section{Introduction}

In 1866 during excavation of the forum basilica a bronze eagle figurine was found and Joyce identified it as an eagle from a legionary standard or Aquila (Joyce 1881, 363-5). However, it was in 1957 that Boon first suggested that the eagle was more likely to have come from a statue of Jupiter or an emperor with its talons curved as if to sit on a globe and this interpretation has been accepted ever since (Boon 1957, 100; e.g. Toynbee 1964, 129; Henig 1995, 97). Although often referred to in discussions of art in Roman Britain, there has been little discussion of the eagle itself and a reappraisal of its function and date and of the use of eagles in Roman Britain is overdue.

Traditionally, analysis of Romano-British art has focused on quality and aesthetics, whether objects were imported or made in Britain, and if made in Britain whether they were produced by native or immigrant artists. In recent years discussions concerning artefacts in archaeology have been much concerned with the topics of agency and identity. Most important here, perhaps, is the idea that objects themselves have the power to affect how people interact with them. For example, Gosden (2005) examined the transition from Late Iron Age to Roman Britain precisely because it was a time of great change, but particularly in the material culture both imported to and produced within the province. Art is particularly sensitive to cultural identity and instead of viewing it as something which developed in one area then spread out from the centre, it is better considered within the milieu of cultural exchange in which ideas, patterns and objects pass to and fro both within and across groups. New objects or styles may be introduced into an area, but are then taken on and transformed to produce art acceptable to local taste and beliefs (Gosden and Hill 2008, 5). 
Britain had a rich tradition of metalworking in the later Iron Age, but new forms of objects were being introduced both before and after the Roman invasion on a significant scale. Among them were metal figurines and large-scale statues in both metal and stone. Iron Age, or Celtic, art is often abstract in design, although both humans and animals are depicted, and Jope $(2000,92)$ noted that imagery became increasingly more frequent from the second century BC onwards. Thus the Silchester eagle would be something new and interesting for native inhabitants of the city to interact with and as such could have been a powerful object which possessed its own set of rules. Stylistically, the Silchester eagle appears to follow the traditions that emerged in Gaul and Britain in the Roman period, and Henig $(1995,97)$ in particular favours a British origin for the piece. This paper will re-examine the details and consider the life-history of the figurine and assess its context in the light of more recent excavations at the forum-basilica. In addition it will review evidence of eagle remains on Late Iron Age and Roman sites in Britain, consider the symbolic meaning of the eagle and discuss bronze and stone depictions of eagles from Britain and the north-western provinces.

\section{The Silchester eagle (Illus. 1)}

In 1964 Toynbee wrote that the Silchester eagle was 'the most superbly naturalistic rendering of any bird or beast so far yielded by Roman Britain' and, indeed, today the figure remains so (Toynbee 1964, 129). The eagle is $230 \mathrm{~mm}$ long, some $150 \mathrm{~mm}$ high and stands with its head turned slightly up and to the right. The wings are now missing but would have been attached to the back, and the detailed depiction of the plumage all over the body indicates that they were outstretched. Apart from the damage to the feet and the missing wings, the figure is in very good condition.

It was not possible to X-ray the figure or conduct any technological examination such as metallurgical analysis, thus any assessment of the mode of manufacture was made by visual examination only. The figurine was cast using the lost-wax technique in which models are used to produce a mould. A wax model produces a solid object using an investment mould. The model is covered with clay and fired, during which process the wax melts and is poured out, molten metal is then poured into the clay mould and once cool the mould is broken to remove the casting. Meanwhile, a clay model produces a hollow casting. The model is coated in wax, followed by clay around the whole. The inner core is held in place by chaplets, small metal bars placed between the core and the mould. The piece mould is then fired, the wax poured out and molten metal poured in (Hemingway 2000, 39-40). The body of the Silchester eagle (including the tail), wings and lower legs were cast separately, and then assembled. The body of the eagle was cast using a piece mould to produce a hollow casting, while the lower legs are solid, thus were cast using an investment mould. The wings were also probably cast using the latter method. Nothing more can be said of the wings themselves as they are now missing, but their attachment to the body is discussed below, as are the lower legs.

The body appears to have been well cast, the only flaws being a group of small holes underneath the rear of the body (Illus. 2). It seems likely that the figure was cast upside down and the molten metal poured in through one or both of the upper legs. This means that the area underneath, between the legs and the tail, was near the top of the casting. Holes in castings can be caused by a number of factors including gassing, which is a result of an inadequately fired mould with which the hot metal reacts to produce pin holes, and shrink holes where the metal forms only a thin layer within the mould and holes form as the metal cools and shrinks. Some of the holes on the eagle may have been caused in either of these ways, but at least one, the rectangular hole which appears to be on the midline of the figurine, was likely to have resulted from the removal of a chaplet holding the mould in place. 


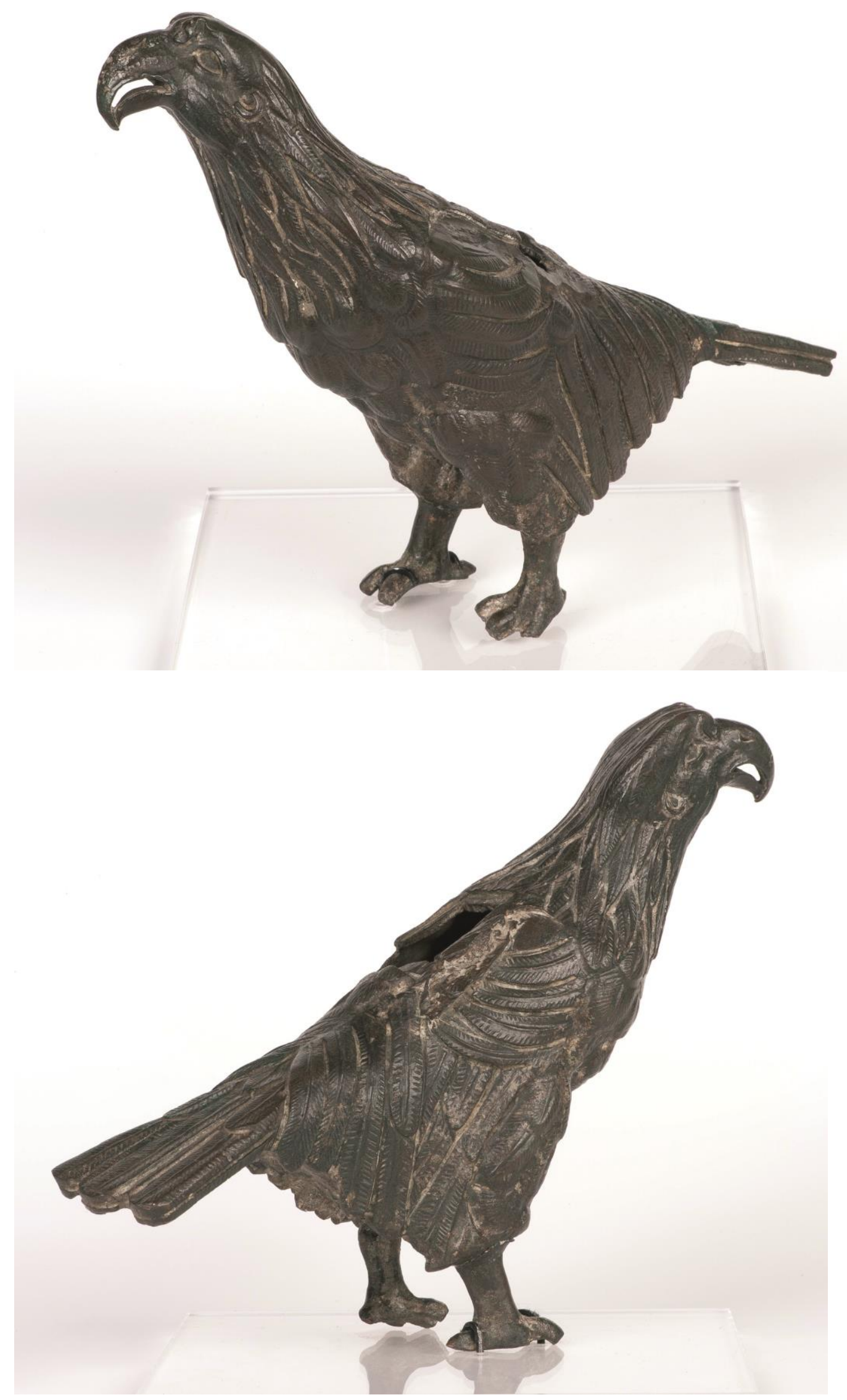

Illus. 1 The Silchester eagle (@ Reading Museum and Art Gallery) 


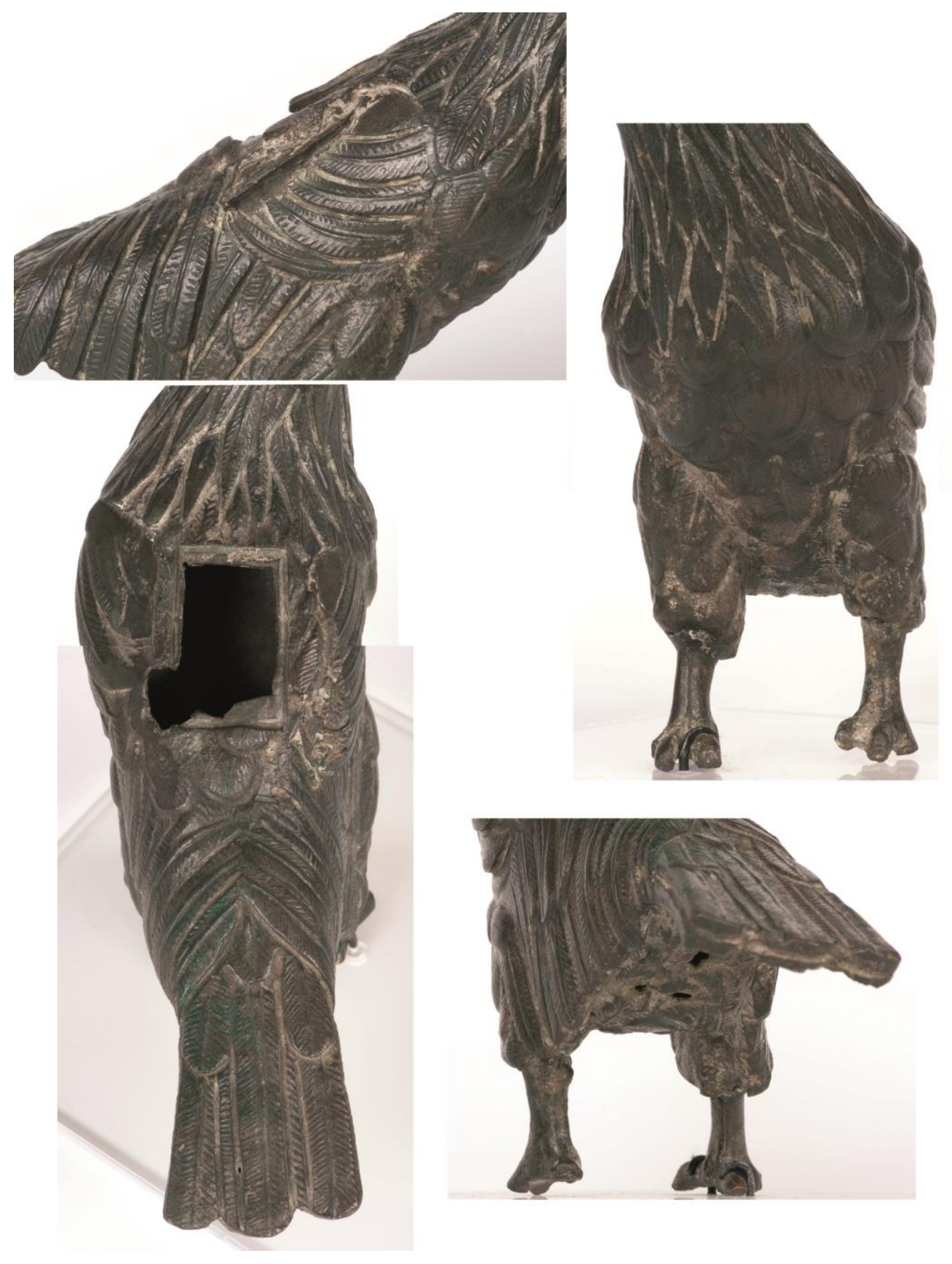

Illus. 2 Details on the Silchester eagle (@ Reading Museum and Art Gallery)

The wing and tail feathers are long, with a central rib along their length and short herringbone grooves on either side. The feathers of the back are curved and taper slightly towards the tip while those on the tail and over the rump are straight-edged with rounded tips. The feathers on the lower part of the neck, breast and thighs are similarly depicted, although somewhat shorter, wider and more rounded, but they become progressively longer and narrower towards the head. The individual feathers are separated by deep, sometimes wide, grooves. The feathers of the breast and thighs are also convex, giving them a fluffy appearance, rather in contrast to the neatly placed feathers across the back, rump and tail. Finally, of some interest is the apparent wear to the feathers of the breast, presumably a result of handling (Illus. 2). 
The detailed depiction of the feathers continues onto the head where the deep ridges on the forehead, in particular on the right side, add to the characterful depiction of the eyes. The beak is large and open wide enough that it might have held an object such as a wreath, as is shown on, for example, several small figurine attachments (e.g. Richter 1956, 39-40 no. 21, pl. XVIII possibly from Egypt; Töpfer 2011, 429, taf. 147 NZ 3.11 from Desa, Romania) and on intaglios (e.g. Henig 1978, 269, no.689, pl. XXI).

The legs are slightly uneven, the feathered upper leg on the right is bulkier and extends lower than that on the left. The lower legs were cast separately and inserted into holes in the bottom of the upper legs. The talons are broken, but the underside of the foot is smooth and slightly curved. The left leg appears to be part of the original figure but the right has been replaced. Most of the talons of the left foot are missing but the leg is better modelled, with a spur at the rear. Without looking closely at the legs it is not immediately obvious that the left leg has been cast separately, while the join is more obvious on the right leg. It is possible to view the top of the legs where they are inserted into the body by looking through the hole in the back. The left leg is well seated in its socket, but the right one does not fit quite so well, it almost appears loose, and extends slightly up into the body of the bird. The foot of the right leg is more complete than the left, and the right leg is thinner and without the spur. However, it does appear that this leg was replaced in antiquity.

A rectangular hole, measuring $38 \mathrm{~mm}$ by $23 \mathrm{~mm}$, takes up a large portion of the upper back (Illus. 2). The top, right and upper left edges show that this hole, with a stepped edge, was part of the original casting. In addition the feathers around the top and sides of the hole are not cut away but end just at its edges. The eagle was cast using the lost wax method and it would be normal to leave a hole to allow removal of the core. The wings could then be attached to the body by a plate fitted into the stepped edge of the hole. Although the hole does seem large, this could in part be due to the need for a secure housing for what would presumably have been sizeable, spread wings. Two factors may have led previous authors to suggest that the wings were replaced in antiquity (Toynbee 1964, 129; Boon 1974, 119): the broken lower left edge of the hole and the chiselling away of the body at the upper left corner and right side of the hole. However, the need to fit the wings securely may have meant that some adjustment of the back was necessary when the piece was first being assembled. Thus the wings may not have been replaced and the damage to the hole occurred when the wings were removed, perhaps forcibly.

The Silchester eagle is a figurine of high quality and its style fits well within the provincial products of Gaul and Britain. Certainly Martin Henig $(1995,97)$ believes it has a British origin, and it could be part of an early tradition of high quality bronzes which is also exemplified by the early second-century head of Hadrian from London (CSIR I.10). The context and, in particular, the date of deposition of the eagle are discussed in the following section.

\section{Context by Michael Fulford}

The Silchester eagle was found on 9 October 1866 in the southernmost of the rooms ranged along the west side of the forum basilica (Illus. 3; Joyce nd; 1881, 365). Like the other fragments of statuary found in the basilica, the eagle, therefore, would date no earlier than the later first century, the date assigned to the forum-basilica then, but a second-century date was also advocated (Toynbee 1964, 129; Henig 1995, 97, 118). As to its context, Boon suggested that the eagle, '... was smashed to pieces for the sake of its metal, no doubt in latest or subRoman times' (Boon 1974, 120).

More recent excavations of the basilica and of the room where the eagle was found suggest a different interpretation of context and, therefore, of date (Fulford and Timby 2000). Of particular relevance was the discovery of a timber predecessor to the masonry building 
first excavated by Joyce. This new discovery is dated to the Flavian period, while the construction of its masonry successor is pushed later, into the second quarter of the second century (Fulford and Timby 2000, 44-68). While the basilica itself produced plentiful evidence of late Roman metalworking, including of copper alloys, as well as of scraps of statuary, the room where the eagle was found produced no evidence of metalworking (Fulford and Timby 2000, 67-78; cf. Joyce nd. , entry for 14 to 22 September).

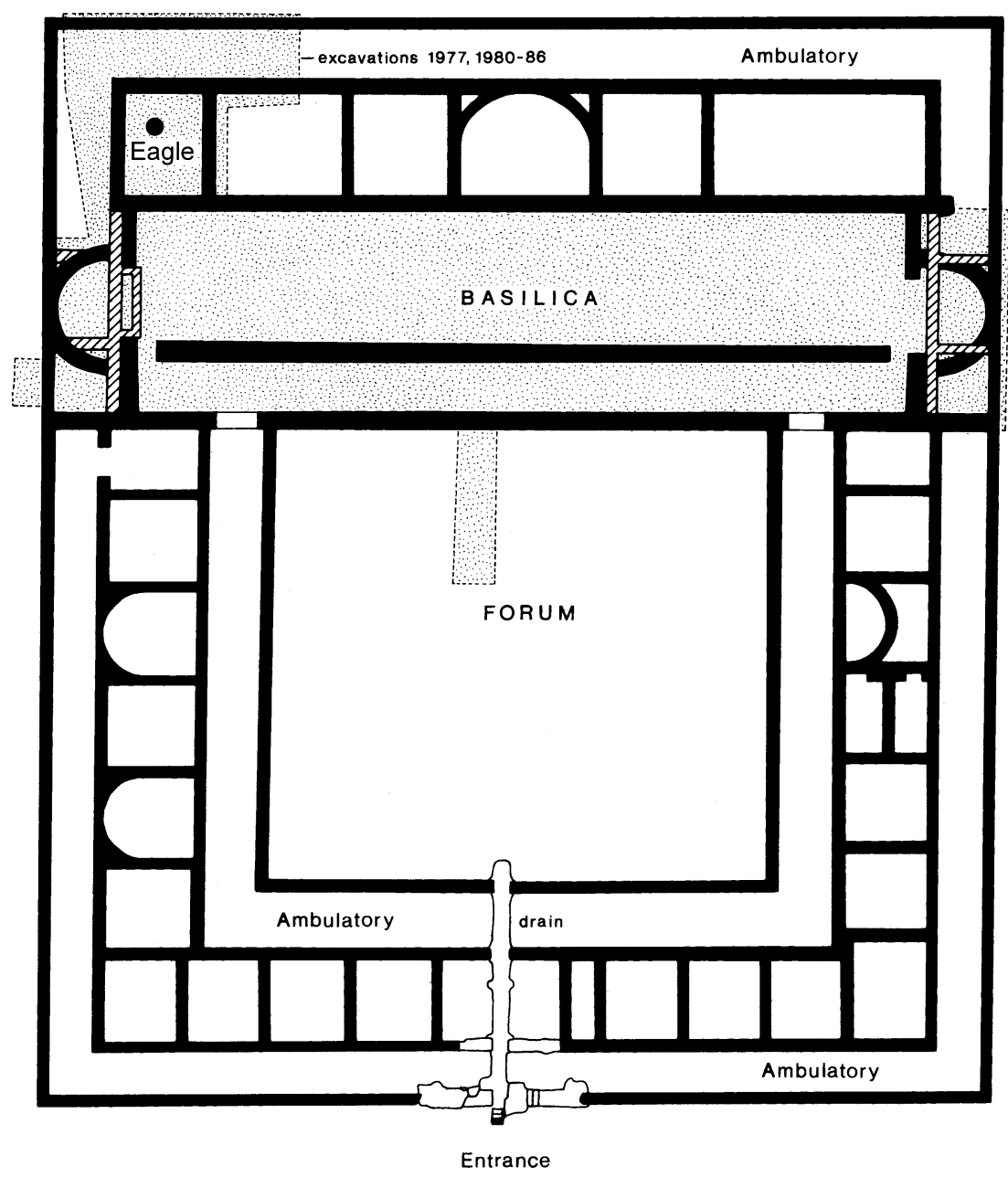

Z27z- later phase

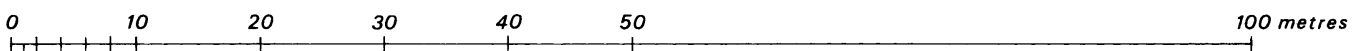

Illus. 3 Plan of the forum-basilica at Silchester showing the location of the eagle

Joyce believed that the eagle fell with the ceiling in the final destruction of the basilica. He described the context:

'.. and here, buried deep, below 10 inches of burnt timber, lay the Bronze Eagle of the Basilica of Silchester, which is the great prize among all our relics. From the position it was found in there can be little doubt as to how it got there. It fell, 
unquestionably, in or with the timbers of a flat ceiling down upon the floor below it. The course of the beams which had carried that ceiling was very distinctly marked by streaks of darker colour, parallel to each other, running from east to west, and from 2 to 3 feet apart, in the stuff and debris on the floor level.... Above these marks of beams there were two seams of burnt timber, the lowermost 4 inches deep and the uppermost 10 inches, and between the two seams was a layer of mortar, stucco, and concrete, 4 or 5 inches thick. The eagle was in this layer of mortar and stucco, immediately under the upper and thicker seam of burnt wood, and at the centre of the room.' (Joyce 1881, 365)

This is based on three entries in his journal, one an annotation of an entry for 27 September 1866, the second the entry for 9 October:

'Referring to the sketch plan of the forum, to the room marked I under Sept 27th, and also referring to the section of the same Room showing the layers of charred wood and debris of concrete and mortar; there was found today at about the centre of the area of this floor, in the bed of mortar and concrete with broken tiles (this author's italics), immediately beneath the greater and uppermost layer of burnt wood, a bronze eagle which is accurately represented on the opposite page.'

The entry for 27 September includes a cross section of the Room in ink and watercolour accompanied by a commentary and a footnote:

'The above section cut from the field level at top, straight down to the natural gravel at the bottom, shows very clearly the condition of this room. At $1 \mathrm{ft} 4$ inches below the field a bed of burnt timber extends pretty evenly, deeper at its centre, where it reaches a perpendicular depth of 10 inches. This bed of burnt matter is so reduced by fire that it shows no traces of wood fibre, but is of a very black hue, below it is a course of mortar and concrete thickly interspersed with tiles, a second layer of burnt materials then occurs, 2 inches only in depth, beneath this is a bed of rubble 6 to 8 inches thick, and then the natural gravel is met.'

At the bottom of the page, a note was inserted: 'NB Oct 9 It was under the above burnt wood that a bronze eagle was discovered, for which see the Journal of that date.'

The third entry from the Journal for 12 October 1866 described the completion of the excavation of the room. Towards the end of this entry Joyce wrote:

'The floor being laid open, to a level immediately below the lowest (sic) of the two beds of charred wood, (there being no actual trace of floor level, such as pavement laid in its place anywhere) when one stands above the room looking across it westward, the eye discerns certain wide streaks of darker colour parallel to each other which cross from east to west being about 2 to 3 feet distance apart; they have the appearance of bars of blackish material, marking perhaps the course of certain beams of a ceiling which had fallen down and rested here.'

This concluded the account of the excavation of the room which had begun between the 14 and 22 September and had then continued intermittently over about three weeks, Joyce himself only being present from time to time.

This room was re-excavated in 1977 as part of an evaluation to assess the extent of plough damage on the Roman buildings within the walled area. Clearance of the Victorian backfill re-exposed the dark streaks which Joyce had observed in 1866 (Fulford and Timby 2000, 67-8, fig. 70). These had little surviving depth and lay in the uppermost surface of the gravel make-up of the room. Partial re-excavation of Joyce's east-west trench across the floor 
of the room showed a profile of dumped make-up, similar in composition to Joyce's description and also of the basilica itself. The lower of Joyce's two seams of 'burnt timber' could be seen as a lens of charcoal within the make-up; the upper layer had been completely excavated away. Three observations may be made about Joyce's findings. First, since the traces of the timbers are embedded in the gravel make-up, the collapsed ceiling timbers can be more plausibly interpreted as the remains of charred floor joists. Second, given that what Joyce believed to be the remains of ceiling timbers had survived his excavation, it cannot be the case that the floor had been 'laid open to a level immediately below the lowest (sic) of the two beds of charred wood' (Joyce nd, 12 October). He surely meant the higher not the lower. Third, in the account for the 9 October, the day when the eagle was found, Joyce noted that it was found 'in the bed of mortar and concrete with broken tiles' (full excerpt quoted above). This strongly suggests that the eagle was found in the makeup of the floor and beneath what are now believed to be the remains of floor joists and thus was not related to the fire which destroyed the forum-basilica but was perhaps a foundation deposit. This being the case, the date of the context of the eagle is $c$. AD 125-50, which implies an earlier likely date for manufacture, i.e. in the first century AD.

\section{Statue or standard?}

It was Joyce who first identified the Silchester eagle as a legionary standard, famously inspiring Rosemary Sutcliff to write The Eagle of the Ninth, published in 1954. However, it was in The Silver Branch (1957) when Sutcliff describes the rediscovery of the lost eagle of the Ninth at Calleva, wingless and battered yet 'defiant in its furious pride' and its subsequent loss during the attack on the town by Allectus $(1980,176,218-220)$ where Joyce's romantic description of how the eagle might have come to rest in the basilica is most evident:

'If we assume this eagle to have been once the Imperial standard of a Roman legion, some aquilifer of the revolted troops shut up here as a last stand, despairing of its safety and of his own life, and whilst the whole western side of this basilica was beleaguered, rather than surrender his trust tore away the bird from the fulmen which its talons had grasped upon the summit of its staff, wrenched off its wings, fastened only by an attachment to its back, and hid it in the wooden ceiling of the aerarium, placing it above a beam, as Romans are known occasionally to have secreted treasure. He himself, no doubt, perished in the melée' (Joyce 1881, 363-4).

However, in order to assess whether the Silchester eagle may have in fact belonged to a standard or statue one needs to consider both how eagles are depicted in the Roman world and other examples of eagle figures.

In the Roman world the eagle was seen as 'the symbol and agent of apotheosis after death' and an eagle was released from the top of an emperor's funeral pyre to signal the journey of the soul heavenwards. Eagles were also depicted in this role on monumental art, however, the eagle was not reserved only for the ruling class but was also found on funerary altars of private citizens (Toynbee 1973, 242).

The eagle, along with the thunderbolt and sceptre, is one of the most common attributes of Jupiter (Toynbee 1973, 240). The image of Jupiter standing holding a thunderbolt in one hand and a long sceptre in the other, with an eagle at his foot, wings slightly spread, looking up and awaiting command was a popular image in the Roman world (Horn 1972, 77). Jupiter is found in this pose on top of the Jupiter columns which were particularly common in the Rhineland in the late second and early third centuries AD but which are found scattered across Europe, including Britain (Woolf 2001, 118; for a full discussion of distribution and dating see Bauchhenss and Noelke 1981). Other figures depict Jupiter Tonans (Jupiter with his left hand raised and drapery across the left shoulder and right forearm) with an eagle standing at his right foot (e.g. LIMC 351, nos 292 and 293). 
Eagles also accompany a seated Jupiter, and this is in fact the most common pose used on Jupiter columns (Bauchhenss and Noelke 1981, 7, 275). Two statues from Trier show eagles at the left foot of Jupiter (CSIR IV.3, taf. 31 no. 104, taf. 33 no. 109). Meanwhile a marble statuette of Jupiter, probably from Rome, shows him seated with an eagle to the left and Cerberus to the right (British Museum accession number 1805, 0703.9. Height $600 c$. $\mathrm{mm}$ ). Of more interest is a third statue from Trier showing an eagle on top of a globe to the right of a seated Jupiter (Illus. 4; CSIR IV.3, no. 100).

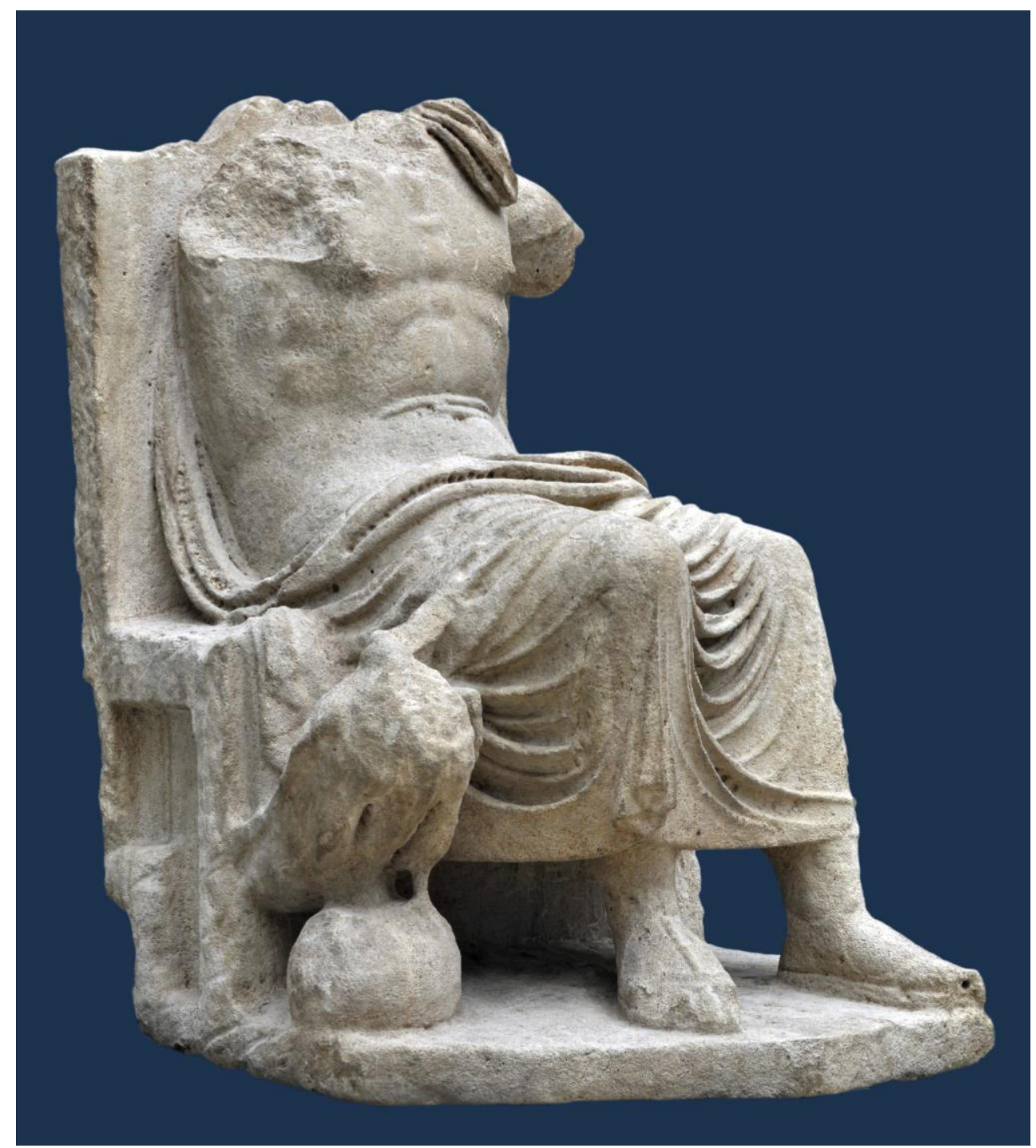

Illus. 4 Statue of Jupiter from Trier, inventory number 11430 (@ Rheinisches Landesmuseum Trier, Th. Zühmer)

In addition to accompanying Jupiter himself, eagles are found on representations of emperors as Jupiter. Two nearly identical, marble depictions from Lanuvium, Italy and Olympia, Greece, dated to AD 42-43 and AD 41-43 respectively, depict Claudius holding a sceptre in his left hand, with the eagle by his right foot (Kleiner 1992, figs 106 and 107). A third marble from Piraeus, Greece shows Balbinus in the same pose and is obviously modelled on the earlier Claudian pieces (Kleiner 1992, 366, fig. 327). A final standing figure 
from Séguret, France depicts Jupiter as a Roman general in which he is shown with an eagle, wheel and snake (Esperandieu 1907, 228 no. 303).

Eagles are also shown with seated emperors, such as that accompanying Augustus on the Gemma Augustea, a cameo from Vienna (Megow 1987, 155-63, Taf. 3, A10). While Boon suggested that the eagle's talons were curved to stand on a globe, depictions of the bird in that position are less common. Apart from the example from Trier mentioned above, of particular relevance here, perhaps, is the marble statue of Claudius from the Foro Vecchio, Leptis Magna. Libya. This statue depicts a seated emperor holding a sphere in his right hand (Niemeyer 1968, 106 no. 89, taf. 30). Fragments of a copper-alloy eagle were found in association with the statue and a suggested reconstruction shows the eagle seated on top of the globe (Horn 1938, 738, Abb. 51). There are also figurines of eagles standing on a globe which were attachments on other objects such as carriages or furniture. Examples from Munzach, Switzerland and Milan show an eagle with wings raised (Tschudin 1962: Munzach eagle height $53 \mathrm{~mm}$; Milan eagle height $105 \mathrm{~mm}$ ).

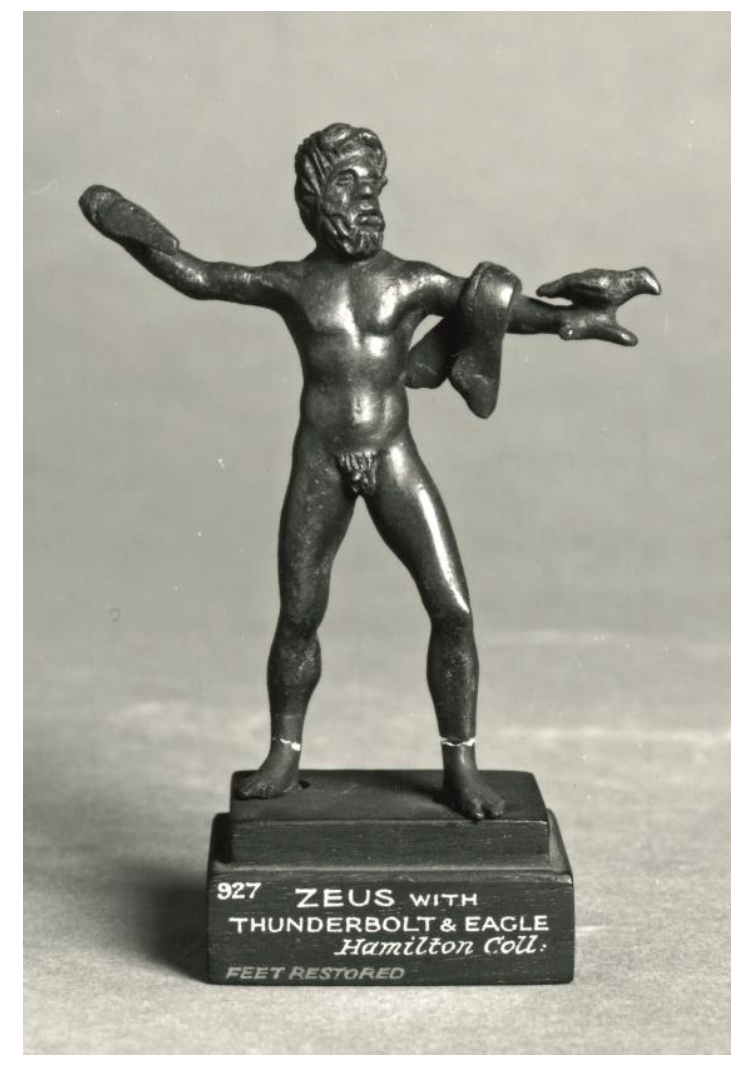

Illus. 5 Unprovenanced bronze figurine of Jupiter, Accession Number 1772,0302.177.c (C) Trustees of the British Museum)

Other depictions of eagles held in Jupiter's hand include a small group of metal figurines. A crude figurine in the Musée des Antiquités de Rouen is thought to be a preRoman example from North Italy (Esperandieu and Rolland 1959, 21 no. 1. Height 98 mm), although the type is a Late Archaic form popular in the fifth century BC in the Peloponnese (Kaufmann-Heinimann 1977, 19). The Rouen Jupiter wears a mantle draped over his left shoulder. He stands with his right leg straight and slightly behind him, while he lunges forward onto his bent left leg, with his arms outstretched. The right arm is to the rear, with the elbow bent upwards. His left arm is held out straight with the eagle sitting directly on his 
wrist. Similar, later examples are an unprovenanced figure in the British Museum with a mantle draped over the left arm (Illus. 5; Walters 1899, 172 no. 927. Height $100 \mathrm{~mm}$.) and a Jupiter without drapery from Banasa, Morocco (Boube-Piccot 1969, pl. 213. Height 80 mm). Meanwhile a Roman example from Augst, Switzerland shows a nude deity in the same stance, although the left arm is to the front and the eagle sits on a globe on the upturned palm with his wings folded (Illus. 6; Kaufmann-Heinimann 1977, 19 no. 3. Height 78 mm). A third example from Laufen, Switzerland shows Jupiter with a mantle over his left shoulder while the eagle sits, with his wings folded, directly on the palm of his right hand (Leibundgut 1980, 14, taf. 3 no. 2. Height $67 \mathrm{~mm}$ ). These figures are based on the classical image of Zeus Aetophoros, meaning 'eagle bearing', in which the god, often seated, has an eagle on one hand while he holds a sceptre in the other. Other images of Zeus Aetophoros can be seen on coins and gems (Jones 1986, 6). Zeus Aetophoros is usually depicted seated on coins of Alexander the Great in the late fourth century BC (Jenkins 1972, nos 497, 499, 501) and on Seleucid coins of the late third century BC (ibid., no. 582). Meanwhile several first-century intaglios show him standing: a cornelian from Pompeii (Pannuti 1983, 4-5 no. 2) and two glass intaglios from Vienna (LIMC 357, nos 346 and 348).

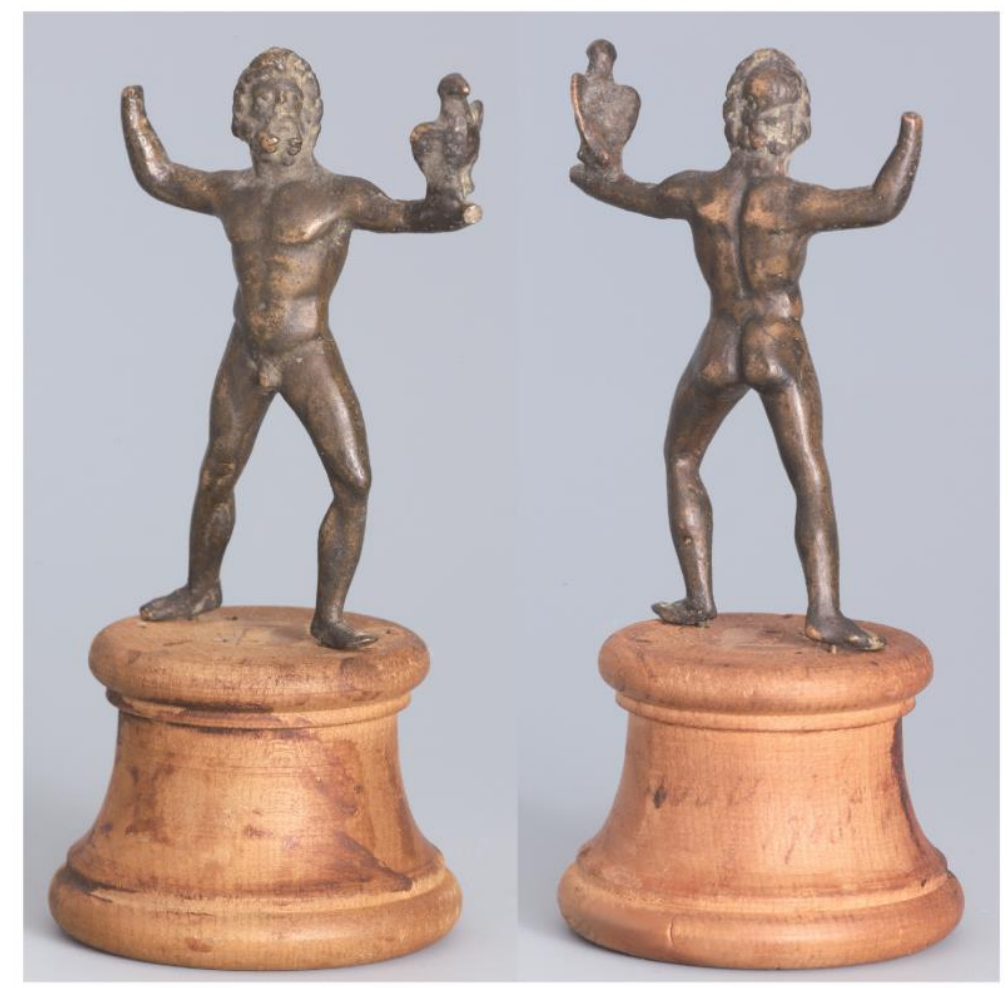

Illus. 6 Bronze figurine of Jupiter from Augst, inventory number 06.111 (C) Historisches Museum Basel)

Perhaps even better known than the eagle accompanying Jupiter or an emperor is the eagle on the legionary standard. The eagle was adopted as the principal emblem of a whole legion under Marius in $104 \mathrm{BC}$ (Pliny $H N$ 10.5.16). These legionary emblems were in silver or gold and stood on a thunderbolt with their wings raised (Toynbee 1973, 241). There are many images of legionary eagles, often on tombstones (e.g. tombstones of Gnaius Musius of Legio XIIII Gemina in Mainz (CIL XIII.6901; Stoll 2007, 458) and Titus Flavius Surillio of Legio II Adiutrix in Istanbul (Speidel 1976, 124)) and coins, such as first-century coins of 
Caligula, Nero and Galba (Mattingly 1923, pls 29 no. 12, 40 no. 14, 58 nos 1-2). Military eagles also appear on intaglios, including first-century AD examples from Hod Hill, Dorset of an eagle with spread wings between two standards (Henig 1978, 271 no.708, pl. XXII) and from Great Casterton, Rutland of an eagle on an altar (Henig 1978, 270 no.705, pl. XLIX). In Britain a legionary eagle is shown on a distance slab from Hutcheson Hill on the Antonine Wall (Illus. 7; CSIR I.4 no. 149). The eagle was also used as a symbol of the Praetorian Guard or as the legionary signum of a unit. However, the depiction of these eagles did not always follow the same simple formula of the legionary standard, and were sometimes decorated with other symbols such as wreaths (Speidel 1976, 139). Many images of standards, including those with eagles, can be seen on Trajan's Column (e.g. Coarelli 2000, pls 5, 9, 26, 27, 50 (which also shows a standard bearing a ram, the symbol of the I Minervia Pia Fidelis), 53, 62 and 63 (in which the wings of the eagle are not spread), 90 and 125).

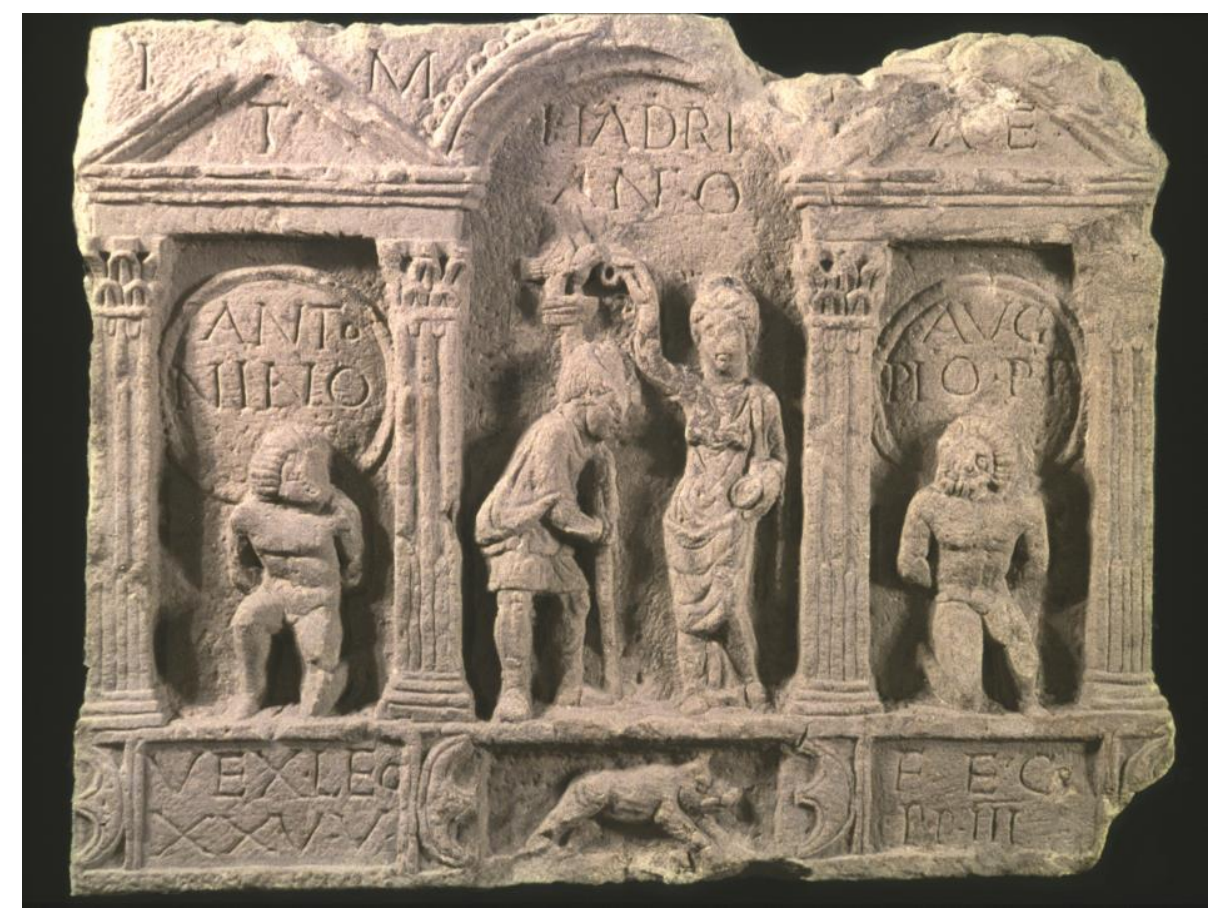

Illus. 7 Distance slab from Hutcheson Hill, accession number GLAHM F.1969.22 () The Hunterian, University of Glasgow 2013)

There are few eagle figurines in the Roman world of the same size as the Silchester eagle, but there is a slightly smaller example from Avenches, Switzerland which is $145 \mathrm{~mm}$ in height, although its legs are broken (Illus. 8; Leibundgut 1976, no. 47). This piece also stands with its wings outstretched, head raised and turned to the right, and like the Silchester eagle, the Avenches figure is highly detailed, with an expressive face. Two other eagles from Buderich-Perrich on the Rhine in Germany (Horn 1972) and Carbedo in north-west Spain (Illus. 9; Arce et al. 1990, no. 67) have their wings folded across their backs. The figure from Spain in particular is depicted in a very different style to that of the Silchester eagle. The feathers, especially those on the front of the body, are quite stylized. In terms of style, the Avenches figure most closely matches that of the Silchester eagle, in particular the depiction of the tail feathers. The Silchester eagle is certainly the most realistic and best executed of the four. In fact the Perrich eagle was very poorly made, with numerous casting flaws which were patched up, probably both when the figure was first made and later during its use (Horn 1972, 64-6). 


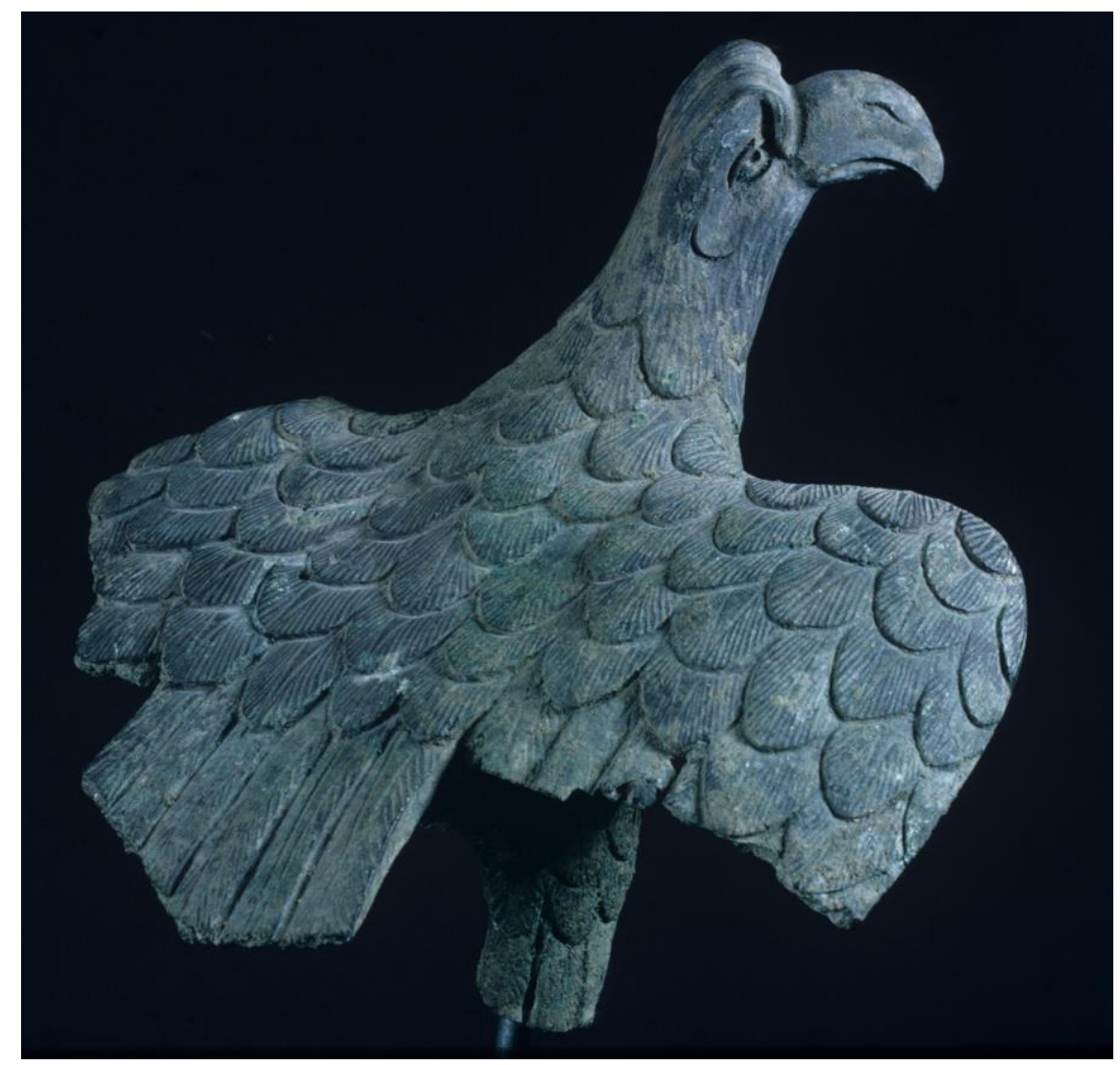

Illus. 8 Bronze eagle from Avenches, Switzerland, inventory number 59.1 (C) AVENTTCVM — Site et Musée romains d'Avenches)

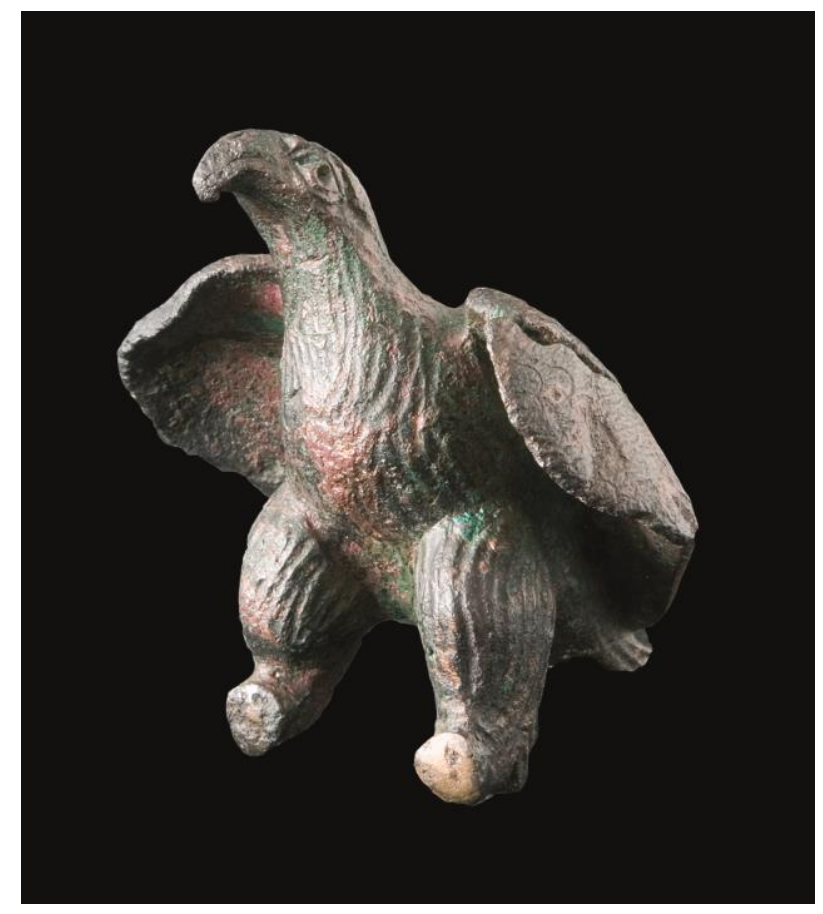

Illus. 9 Bronze eagle from Carbedo, Spain (ㅇ Museo Provincial de Lugo) 
Stylistic dating is fraught with problems, such as the continued use of particular styles or details in some provinces long after they have been replaced elsewhere, thus the recovery of objects from well-dated contexts can be of particular importance in helping to date figurative pieces. Unfortunately, the contexts from which the eagles other than the Silchester example were recovered are also not particularly useful. The Spanish eagle is from the cemetery on the castro, or hillfort, site of El Caurel, although the exact context is unknown. An inscription dated to AD 28 was also found in the cemetery (Garcia y Bellido 1966, 37-8; Luzón Nogué and Sánchez-Palencia Ramos 1980, 36). Unfortunately, the Perrich eagle was recovered during gravel extraction and is without a context, although it was found with other Roman objects (Horn 1972, 63). Meanwhile, the Avenches eagle was found by the side of a Roman road and Leibundgut suggests a date in the later second century (Leibundgut 1976, 64). Neither Horn nor Leibundgut feel that these eagles are military, Horn suggesting that the Perrich eagle most likely accompanied a statue and Leibundgut that the Avenches eagle was an attachment.

\section{The eagle in Britain and the Roman world}

Before further discussing artistic representations of the eagle in Roman Britain, the species present in Europe at the time and their occurrence on British archaeological sites is examined. Two species of eagle are known to have lived in Britain during the Roman period - the white-tailed or sea eagle (Haliaeetus albicilla) and the golden eagle (Aquila chrysaetos). While the golden eagle still breeds in Britain, the white-tailed eagle became extinct here due to deliberate exterminations in the eighteenth and nineteenth centuries, although its reintroduction is under way (Brown 1976, 85; Parker 1988, 217; Serjeantson 2006, 233; Yalden 2007, 471; Yalden and Albarella 2009, 194-8). The golden eagle is a powerful bird with a large bill and long tail, but while the golden eagle is the largest raptor now extant in Britain (length 0.75-0.88 m, wing-span 2.04-2.20 m), it is of similar size to the white-tailed eagle (length 0.70-0.90 m, wing-span 2-2.4 m). The white-tailed eagle has a large, deep bill, a short tail and the tarsus is unfeathered (Brown 1976, 86, 175; Cramp and Simmons 1980, 48, 234). The white-tailed eagle lives on coastlines in Europe, as well as near rivers and lakes, and will feed on fish, mammals and carrion. The willingness of this eagle to scavenge means that it can benefit, from association not only with humans who hunt or raise livestock, but also urban environments (Brown 1976, 85-6; Mulkeen and O'Connor 1997, 441-2; Yalden 2007, 471-3; Serjeantson 2009, 376). Indeed Pliny mentions that the white-tailed eagle is found in towns and open country (Pliny $H N$ 10.3.7). In contrast, the golden eagle is a predator rather than a scavenger and this suggests that it was less likely to exploit an urban habitat. It tends to inhabit mountainous and upland regions, although it is also found in lowland forest and wetlands where there is a low population density (Cramp and Simmons 1980, 234; Mulkeen and O'Connor 1997, 441). Although today the distribution of the white-tailed eagle is largely restricted to northern and eastern Europe and Russia, both of these eagles were more widespread during the Roman period and were found in much of Europe as well as in Asia Minor and the golden eagle occasionally in North Africa. A number of other eagles were present in parts of Europe, Asia Minor and North Africa (e.g. Bonelli's, booted, imperial and short-toed) but none of these reached Britain (Cramp and Simmons 1980, 51, 235, 258).

One factor that affects the recovery of bird bones during excavation is their small size. It does appear that the limb bones of chickens and larger birds, such as the eagle, are collected by hand excavation, but that sieving is necessary to recover smaller bones (Parker 1988, 201; Serjeantson 2009, 128). The bones of the white-tailed and golden eagles can for the most part be distinguished morphologically (Yalden and Albarella 2009, 12) which means that the majority of the eagle bones recovered can be assigned to a species. Eagle bones, while not common on archaeological sites, have been recovered from some twenty sites of 
Roman date (Table 1). All of the identified specimens are of the white-tailed eagle, except for a golden eagle bone from the roadside settlement at Bainesse Site 46, Catterick, North Yorks. (Meddens 2002, 420, tab. 132). White-tailed eagle bones have been recovered from at least eight Iron Age sites (Yalden 2007, tab. 2) including two sites from which eagle bones of Roman date have also been found: the settlements at Dragonby, Lincs. and Haddenham, Cambs. The animal and bird remains from both of these sites are somewhat unusual; nearly three quarters of the bird remains from Dragonby are from the accipiter (eagle/buzzard/kite/hawk) and corvid (crow) families. Many of the eagle bones were recovered from two ditches, and in particular from ditch F1395/96 (Harman 1996, 163). Meanwhile, the enclosure at Haddenham on the fenland margins contained a high proportion of wild animals, especially beaver, swan and other wild fowl. Apart from the three eagle bones, the majority of the bird bones are comprised of swan, mallard and coot, but also include pelican and crane, which like the white-tailed eagle later became extinct in Britain (Serjeantson 2006, 213, 227, 233).

\begin{tabular}{llllc}
\hline Site & Site type & Date & Reference & No. \\
\hline Dragonby & Settlement & MIA-early Roman & Harman 1996 & 73 \\
Haddenham V & Enclosed farmstead & LIA & Serjeantson 2006 & 3 \\
Sheepen, Colchester & Military industrial & mid-1st c. AD & Luff 1985 & 19 \\
Caerleon & Fortress & AD 50-100 & Hamilton-Dyer 1993 & 3 \\
Binchester & Fort & late 4th-mid 5th c. & Cussans \& Bond 2010 & $>50$ \\
Caernarfon & Fort & late 3rd--late 4th c. & O'Connor 1993 & 6 \\
Caister-on-Sea & Fort & 4th c. & Harman 1993 & 1 \\
Pasture Lodge Farm, & Enclosed farmstead & 1st-3rd c. & Harman 1994 & 1 \\
Long Bennington & & & & \\
Bainesse, Catterick & Settlement & AD 150-300 & Meddens 2002 & 1 \\
Tolpuddle Ball & Settlement & 1st-4th c. & Hamilton-Dyer 1999 & 1 \\
The Lanes, Carlisle & Small town & AD 150-200 & Connell \& Davis 1998 & 1 \\
$\begin{array}{l}\text { Durocobrivae, Dunstable } \\
\text { Stonea Grange }\end{array}$ & Small town & late 1st-early 2nd c. & Matthews 1981 & 1 \\
Scole-Dickleburgh & Small town & early 3rd c. & Stallibrass 1996 & 1 \\
Leicester & Small town & 3rd-4th c. & Albarella \& Pirnie 2008 & 1 \\
London & Urban & mid-3rd c. & Baxter 1993 & 1 \\
Southwark, London & Urban & late Roman/Saxon & Cowles 1980 & 1 \\
Bays Meadow, Droitwich & Villa & mid-3rd c. & Rixson 1978 & 2 \\
Redlands Farm, Stanwick & Villa & AD 150-300 & Bramwell 2006 & 8 \\
Snow's Farm & & late 4th-5th c. & Davis 1997; Albarella \& & $1(+1$ ?) \\
Haddenham III & Religious & & Prinie 2008 & 1 \\
Uley & & 1st-3rd c. & Beech 2006 & \\
\hline
\end{tabular}

Table 1: Sites of Roman date from which eagle bones have been recovered

The other two sites from which more than eight bones have been recovered are both military. At the early Roman military metalworking site of Sheepen, Colchester, Essex some nineteen bones from two eagles were found in a feature along with two nearly complete ravens, a complete dog and a puppy (Luff 1985, 148). Other military sites from which eagles have been recovered are the fortress at Caerleon, Gwent and the forts at Binchester, Co. Durham; Caernarfon, Gwynedd and Caistor-on-Sea, Norfolk. The three bones from an immature eagle were recovered from the site of the residence of a senior legionary officer at Caerleon where they were found in a well; meanwhile a second well contained sixty-two bones from at least four cranes, which may have been part of a high status meal at the officer's house (HamiltonDyer 1993, 135-6). At Binchester eagle bones were found in three phases of late Roman and 
sub-Roman date. Among these are thirty-six bones from one layer, over half of which are wing bones which bear butchery marks attesting to the removal of the wings (Cussans and Bond 2010, 522-3).

The only other site type from which a group of eagle bones was recovered is the villa at Bays Meadow, Droitwich, Worcs. Here among the eight bones is a pair of complete femora, although the other bones were fragmentary (Bramwell 2006, 221). Finally, only single or pairs of bones were recovered from eight other urban, rural and religious sites. A white-tailed eagle skeleton was found within a cess pit at Dunstable, Beds., along with a number of small rodent, frog and water vole bones which the author suggests may have been food for the eagle (Matthews 1981, 67). The two bones from a mid-third-century well deposit at 8 Union Street, Southwark were found with three triple vases, a partial red deer skull and antler which suggest they may have been part of a votive deposit (Rixson 1978, 223-4, 232). The single bone from Leicester is a skull, also from a mid-third-century well. Other bones in the deposit include a high proportion of wild species and immature domesticates, among them two piglets, two partial kittens and young dogs, a partial crow and jackdaw and the heads or jaws of young cattle and sheep/goat. The eagle skull bears marks which show that the bird was decapitated and the beak removed. Beaks and claws are known to have been used as talismans in prehistoric Europe (Baxter 1993, 31-2, 36).

It is interesting to note that in many of the published reports the authors seem reluctant to suggest that the presence of eagle bones may have been part of a special deposit and are more likely to suggest that eagles may have been killed as a nuisance when scavenging on settlement sites (e.g. Parker 1988, 208; Cowles 1993, 266). This may well be true in some cases, and yet many of the eagle bones do seem to appear in unusual assemblages or deposits which suggest something more than casual inclusion of the bones on the site. Fulford (2001) has examined the continuity of structured deposition in pits and wells from the Iron Age into the Roman period in which animal and bird bones often played a part. It is known that ravens were part of special burials at sites such as Danebury, Hampshire and Silchester, and that sometimes eagle bones were included in these deposits (Serjeantson and Morris 2011). Thus, as Serjeantson and Morris (2011, 102-3) point out, the question of whether authors see the deposition of eagle bones as resulting from their role as scavengers or as votive offerings is often a result of the simple identification of the bones as opposed to an interpretation of their context. The wing bones from Binchester are interesting as eagle and goose wings have in the past been used as brushes while the feathers were used for quills and arrow flights.

Feathers have been attributed special powers throughout history and used not only for decoration but also as good luck charms and on ritual or martial objects such as headdresses, masks, cloaks, weapons and shields. Their meanings are various, but the use of feathers from particular species can signify, for example, social standing, prowess in battle or personal achievement (Serjeantson 2009, 185; Sillitoe 1988, 301). They are also used as a form of sympathetic magic and eagle feathers are highly desirable in many cultures for their association with qualities necessary for success in hunting and warfare (Parker 1988, 201; Serjeantson 2009, 186). A number of the ravens from Danebury had their wings removed, possibly in order to procure wings/feathers for ritual or display purposes and the deliberate deposition of ravens continued in Britain from the Iron Age into the Roman period (Serjeantson and Morris 2011). Ravens are often associated with shamanism and may well have acted as familiars to shamans or priests in Iron Age and Roman Britain (ibid., 100).

Eagles may have sat at an intersection of native and Roman belief systems. They were closely associated with Jupiter, the premier god of the Roman pantheon, and thus held a special place in the Roman world, although of course it should be noted that they held a similar position with Zeus in the Greek world. Pliny called the eagle the most honourable and 
strongest of birds which became Jupiter's armour bearer as it cannot be killed by a thunderbolt (Pliny $H N, 10.3 .6,10.5 .15$ ). Thus the eagle also became a symbol of strength and success and its flight could be interpreted as an omen. In particular its flight during battle could spur troops on to victory (Curt. 4.15.26; Tac. Ann. 2.17). For others the eagle could be seen as an omen of impending greatness or serve as a warning. In Livy (1.34.8) an eagle plucked the cap off a traveller's head then replaced it. The man carried on to Rome where he became the highly successful Lucius Tarquinius Priscus. Meanwhile Cicero wrote of King Deiotarus who cancelled a journey after seeing an eagle, only to learn that the room in which he had been due to stay collapsed during the night (Cic. Div. 1.15.26). The presence of eagle bones in deposits at Iron Age sites indicates that they may also have had a role in Iron Age religion. They also appear along with bulls as bucket mounts from Ribble, Lancs. and Thealby, Lincs. (Green 1986, 188).

This discussion demonstrates that the people of Iron Age and Roman Britain would have been familiar with the eagle, both as a physical presence and an important symbol of strength and success. Given the similar associations of ravens and eagles as scavengers, oracular and chthonic birds it is possible that the eagle had a similar role to that of the raven in Roman Britain and possibly before.

\section{Jupiter and eagles in Britain}

No other large bronze eagle figures are known from Britain but there are numerous other forms of images of Jupiter and eagles to be found, although depictions of the two together are less common. Some of the earliest images of eagles in Britain are those on the coinage of southern and eastern England. Eagles are particularly prevalent on the coins of the Atrebates, including those of Tincomarus, Eppillus, Verica, Epaticcus and Caratacus and take two different forms: the eagle seen from the front with its wings spread and sometimes holding a snake in its talons (e.g. $A B C 1106$ (Tincomarus); $A B C$ 408, $A B C 411$ (Eppillus); $A B C 1346$ (Epaticcus); $A B C 1376$ (Caratacus)) and the flying eagle seen from the side (e.g. $A B C 1160$ (Eppillus); $A B C 1331$ (Verica)). Eagles are rare on coins in other regions, but there is a coin of the Catuvellaunian kings Rues $(A B C 2670)$ and Cunobelinus $(A B C 2954)$ showing the eagle with spread wings and an imported coin of the Carnutes with the eagle and snake $(A B C$ 109). Creighton sees the adoption of classical imagery on the coins of late Iron Age Britain as a result of the fostering of young princes at Rome and the resulting links between far-flung dynasties. In this case the eagle seen on coins of Tincomarus may be directly linked to that seen on coins of Juba II in Mauretania (Creighton 2000, 121, fig. 4.12). However, while the Mauretanian eagle carries the thunderbolt, the British eagle carries a snake, which Creighton suggests may represent a victory in battle. Briggs $(2013,3)$ sees the eagle with snake as a political allegory in which either of the combatants - the earthbound snake and subject people or the long-range predator and overlord - could be victorious. Eagles of this type are also seen on gems of first-century BC/AD date, such as an unprovenanced example holding what may be a goat in its talons (Henig 1990, 106 no. 179). Meanwhile, the flying eagle would seem to be related more to the depiction of the eagle standard on Roman coins, although without the accompanying signa. Coins of Eppillus showing this flying eagle and bearing the legend CALLE/CALLEV were in fact struck at Silchester, or Calleva Atrebatum as it was then known (Van Arsdell 1989, 415-1; Fulford and Timby 2000, 558). Thus the use of coins bearing the eagle may be seen as an expression of rulers who were not only familiar with Roman customs, but also keen to promote the adoption of Roman ways and that the lack of eagle imagery in the majority of other kingdoms is an indication of the different power structures within these regions which did not adopt a high king in the manner of the Atrebates and Catuvellauni (Briggs forthcoming). 


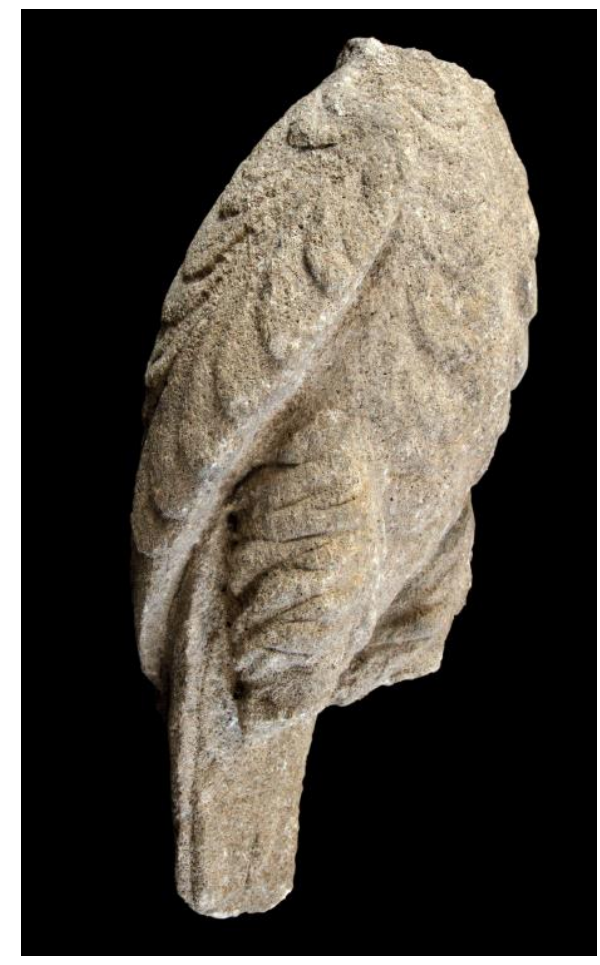

Illus. 10 Stone eagle from Cirencester, Gloucestershire, accession number 1980/120/2 (C) Cotswold District Council)

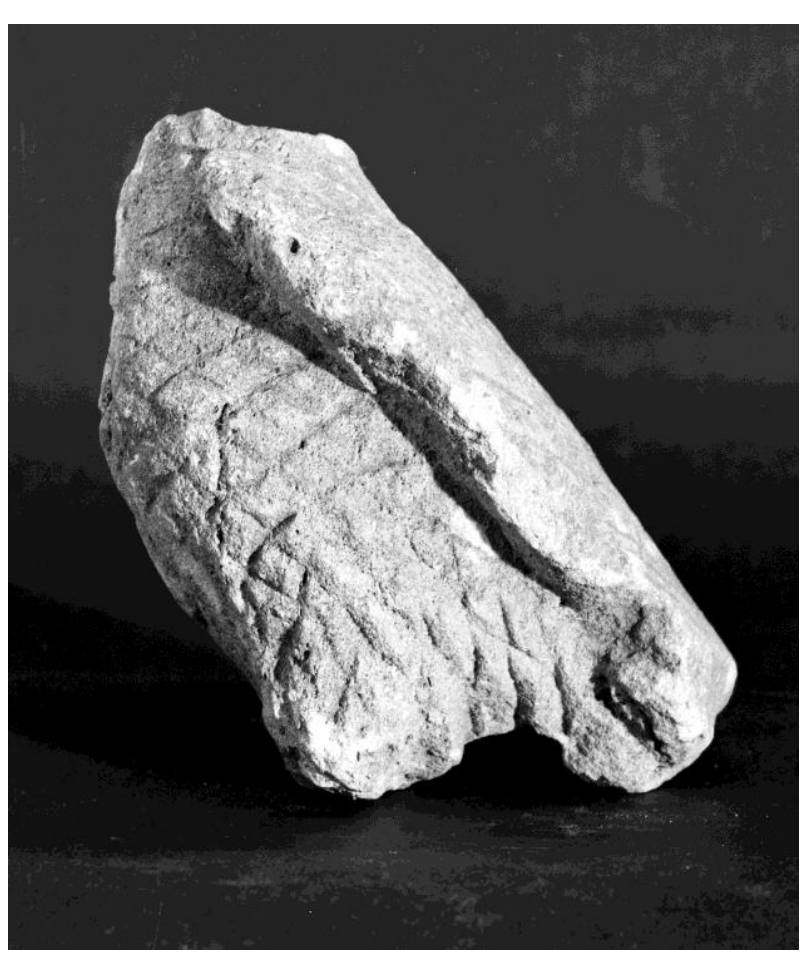

Illus. 11 Stone eagle from Cole's Hill, Gloucestershire, accession number A6274 (C) Gloucester Museums Service)

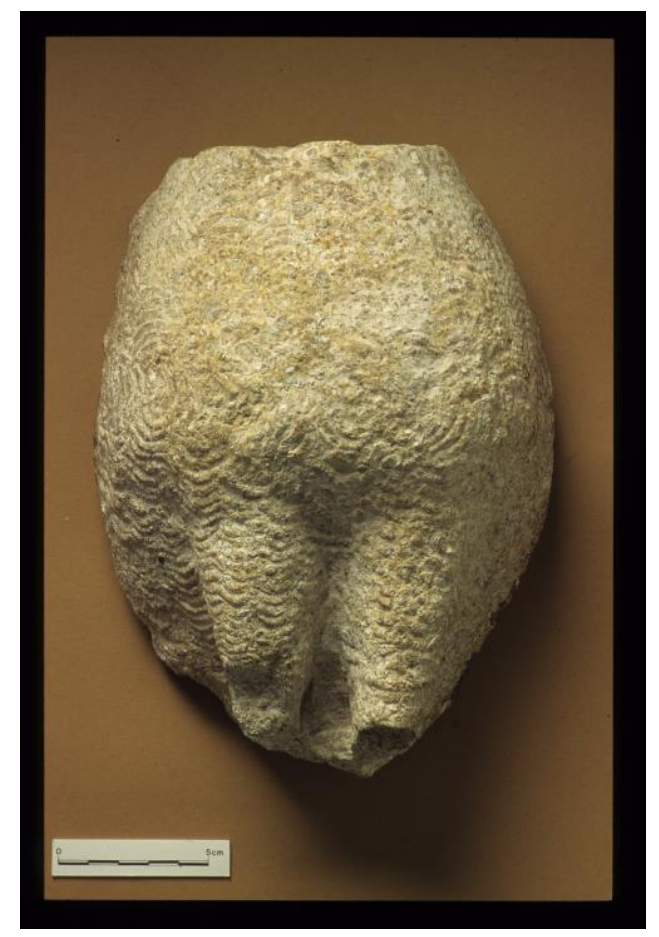

Illus. 12 Stone eagle from Exeter, Devon, accession number 521/1989 (C) Royal Albert Memorial Museum, Exeter) 
As in continental Europe, many British images of Jupiter and eagles are in stone. Of interest here are four stone eagle sculptures. Three are from Gloucestershire (Cirencester, Somerford Keynes and Cole's Hill) and one from Exeter, Devon (Illus. 10-12; CSIR I.7, I nos 166-168, II no. 3). Unfortunately all are missing their heads and all or part of the legs. The Gloucestershire figures are made from the oolitic limestone used by Romano-British sculptors in the Cotswolds. While the Cole's Hill eagle is rather coarsely depicted, those from Somerford Keynes and Cirencester are well executed. The drapery to the right of the Somerford Keynes eagle and the break on the left side of the Cirencester eagle suggest that both accompanied Jupiter. The Cole's Hill eagle was ploughed up in a field half a mile south of the villa at Spoonley Wood, and along with a small uninscribed altar may have come from a small shrine (CSIR I.7, 168). The Somerford Keynes eagle was recovered from a settlement enclosure ditch, from which also came part of an altar and a partial shield with drapery (Frere 1987, 341). The Cirencester eagle was part of a group of five sculptured pieces laid in a line on a metalled surface along the south-east wall of shop building V.6 in the western corner of Insula $\mathrm{V}$, the insula to the west of the forum. The other pieces were three small altars (one dedicated to Mercury and the Mothers) and a small column base. In addition to these pieces, a fragmentary arm from a life-size statue was found in a late Roman pit dating from after the demolition of the building (Holbrook 1998, 225-6). Meanwhile, the Exeter figure is of particular interest here as it appears to date to the mid-first century AD. It was sculpted from Purbeck marble from the Isle of Purbeck in south-east Dorset, a stone which was being used almost immediately after the conquest (Williams 2002, 127-8). However, while Purbeck marble was used for a variety of purposes in buildings and memorials, no other sculptures are currently known, and the darker colour of Purbeck marble may have been chosen to make it stand out from a statuary group (CSIR I.7, 83; Williams 2002, 128). The back of the Exeter eagle is flat and has a small hole towards the upper back which presumably was used to fix the back and wings (or possibly to fix the piece to a frieze if it was part of a piece in very high relief) (Toynbee 1979, 132). The eagle was found in a pit with late first-century pottery, possibly in the principia of the legionary fortress which was in use from $c$. AD 55/60-75 (Bidwell 1979, 17-18). A clean cut below the neck of the bird indicates that it was deliberately decapitated. If the eagle was part of a group with Jupiter or an emperor as Jupiter, then the date suggests Nero, whose portraits at the time of his damnatio memoriae following his death in AD 68 were largely destroyed or given a new head depicting one of his successors, and it may have been defaced at the same time (Toynbee 1979, 130).

The fact that all four of these stone eagles are missing their heads is interesting. As powerful objects perhaps they were all deliberately beheaded (see Croxford 2003 for a discussion on the mutilation of statues). On the other hand, perhaps the bodies were particularly important. In his analysis of fragmentation of objects, Chapman (2000, 23) suggests five possible causes for their entry into the archaeological record: accidental breakage, burial because they are broken, ritual killing, dispersion to ensure fertility and deliberate breakage for reuse in enchainment (creating social or economic bonds). Thus damage or breakage might not mean the end of an objects use, but the beginning of a new stage in its life. One could suggest that the missing head represented a weak point in the statue that led to accidental breakage, however, at least one of the eagles was deliberately beheaded. In addition, experimental fragmentation studies indicate that it is not as easy as one might think to 'accidentally' break something and that breakage patterns do not definitely indicate accidental or deliberate breakage (Chapman and Gaydarska 2007, 7-8). Thus perhaps the eagle bodies were deliberately selected. This is different to the patterns of deposition indicated for human statues in which the head is the most common surviving part (Croxford 2003, 86). If the head was the most important part of the human body, perhaps the body, which displays the feathers, was important for the eagle. 
Metal images from Britain include some twenty-two figurines of Jupiter, all of which are depicted standing except for one seated example from West Stoke, Sussex (Durham 2012, section 3.13). Meanwhile thirty-eight small figurines of eagles have been found, making it the second most popular bird or animal behind the cockerel from Roman Britain. The majority of these eagle figurines are less that $50 \mathrm{~mm}$ in length and are depicted with their wings spread, although there are also some with folded wings. Both Jupiter and eagles are found scattered throughout Britain, but they have not been found in association with each other (Durham 2012, section 3.35, table 5; section 4.4.1, fig. 21). Apart from the figure under discussion here, two other eagles have been found at Silchester. One, a flat bronze figure was probably an attachment while the other is described as a military ensign in steel (Anon. 1789, 370; Anon. 1849, 295). As is so often the case with metal figurines, nineteen of the eagles are from unknown contexts, but they are found at a variety of site types including four from military sites and three from urban sites. Apart for two from villas, they do not occur at rural settlement sites or at religious sites other than the temple at Woodeaton, Oxon. where a small group of five eagle figurines was recovered (Kirk 1949; Henig and Munby 1973; Durham 2012). Also of interest is the eagle figure thought to have been a sceptre terminal which was recovered from the temple at Farley Heath, Surrey. A second sceptre terminal, identified variously as an eagle or raven was also part of the hoard found at Willingham Fen, Cambs. (Bird 2007, 49 no. 81, fig. 21; Rostovtzeff 1923, 94 no. 9, pl. iv, no. 5). Both were found in association with a number of other votive objects. Thus although few eagle bones have been found at religious sites, they do have a presence as objects in bronze. In fact the spread of stone and bronze images of eagles across the country shows that they played a significant role in the artistic and religious traditions of Roman Britain. Like eagle bones these images occur on a variety of site types, but like the Iron Age coins they tend to occur in areas with a strong Roman presence, whether military or civilian.

\section{Discussion}

So what does all this mean for the Silchester eagle? There are no surviving examples of legionary standards in the Roman world, and of the eagle figures known, the majority of authors cite their small size as precluding them from use as standards (Töpfer 2011, 79). The importance of the standard to their military units perhaps meant that they were disposed of carefully, or the fact they were of precious metal meant they had a monetary value that would not wilfully be lost. The Silchester eagle, while certainly of a quality that could proudly represent a unit, is not gold or silver, nor is there any evidence for gilding. The size and design perhaps suggest that the eagle was part of a statue of Jupiter, or of an emperor as Jupiter.

Considering once again the early to mid-second century context from which the eagle was recovered, in the continuing excavations of Insula IX, the discovery of Flavian timber buildings incorporating monumental masonry in their foundations prompted a wider review of the evidence for pre-Flavian monumental building in Silchester. Re-assessment of the context of certain building materials from the 1980s excavation of the forum basilica provided further support for a pre-Flavian monumental building, perhaps a Neronian palace for the client king located in the area of Insulae II and III immediately to the west of the forum basilica (Fulford 2008). The evidential basis for that article was provided by monumental building materials, but the remains of monumental statuary were not considered. However, an association of the two types of find is suggested by the concentration of both fragments of statuary and building materials in the forum basilica and, in particular, the basilica and the associated ranges of rooms to west, north and south. Is it possible that this material derives from the same source and that the eagle and the remains of some or all of the other statuary is of pre-Flavian, i.e. Neronian (or earlier) date? Interestingly, alongside 
monumental building material, one fragment of bronze statuary was associated with the Flavian basilica, while three further fragments were found in the Period 6 make-up of the second-century basilica in the 1980s excavations (Boon 2000a, 350-1, fig. 165, no. 100; 2000b). At the same time Toynbee remarked that the fine bronze lappet found in 1890 in the northern apse of the basilica indicates a cuirass of pre-Hadrianic date (Toynbee 1964, 52). This brings to mind the statue of Jupiter as a Roman general from Séguret, France in which he is shown with an eagle, wheel and snake, as well as the symbol for the god's sacred tree, the oak (Esperandieu 1907, 228 no. 303). This is a curious set of images, combining the role of Jupiter, as patron of the Roman army, and the Celtic warrior and sky god (Green 1989, 118). One might also remember the Atrebatic coins mentioned above on which the eagle is depicted holding a snake in its talons implying a particular connection of the eagle to this civitas.

However, while the Silchester eagle is too small to be standing next to a life-size or larger statue of Jupiter or an emperor, it could accompany a smaller statue. Although rare, the statue from Trier mentioned above provides an example of an eagle standing on a globe accompanying a seated Jupiter. The larger than life-size limestone foot from Silchester (CSIR I.2, 41 no. 147, pl. 37) also brings to mind the statue from Leptis Magna in which a copperalloy eagle accompanies a much larger stone figure.

The high quality of the Silchester eagle suggests that it accompanied a piece of some importance. The style suggests it was of provincial Gaulish or British origin, the latter being favoured by Henig $(1995,97)$. While the Silchester eagle is a very realistic depiction, it is not possible to identify it as a particular species. The long tail and the shape of the beak are characteristic of the golden eagle, while the unfeathered tarsus is seen on the white-tailed eagle. The details of the different feather types, long and thin on the neck, wide and short on the breast, long and wide on the back and tail, do indicate a familiarity with this species of bird.

Calleva in the late Iron Age was characterized by a high proportion of imported, Romanizing goods, particularly pottery and foodstuffs, at a level not seen at other sites in the region, and this may itself have resulted from the establishment of Calleva as a base of the Atrebatic kingdom under Eppillus (Fulford and Timby 2000, 549-60). This was a milieu into which a high-quality piece of statuary and a highly symbolic animal would most likely have been appreciated, whether as a gift to a client king or as a Roman imperial symbol and represents the more traditional interpretation of the Silchester eagle as an imported Roman object used in a 'Roman' fashion. However, the replacement of a leg and the apparent wear to the feathers on the breast raise questions about the history of the figure. While it may have originally belonged with a statue of an emperor or Jupiter, perhaps the eagle had a life independent of that statue. As it is not very large, the eagle could have been easily transported and handled. What did it say to the first- and second-century inhabitants of Silchester? The special deposition of raven and eagle bones, which increased from the Iron Age into the Roman period in Britain has already been discussed. Did the Silchester eagle become part of the ritual life of the town, not representing Roman rule but the religious and social traditions of those who lived there? Perhaps it ended its life as a treasured object, placed as a foundation deposit within the heart of the settlement at Silchester. Whatever form of object the Silchester eagle did once adorn, its deposition may have been an equally important part of its lifehistory. When found it was, and still is, a wonderful piece of art which will continue to inspire questions about the nature of occupation at Silchester in the first century AD.

\section{Acknowledgements}

I would like to thank Martyn Allen of the University of Reading for his help in finding references to eagles in the archaeological literature, John Creighton for providing antiquarian 
references to other eagles at Silchester, Neil Burridge for discussing the technicalities of bronze casting with me and Hella Eckardt and Martin Henig for reading earlier versions of this paper. The photographs of the Silchester eagle were taken by Laura Bennetto of the University of Reading.

\section{Bibliography}

Abbreviations

ABC Cottam, E., de Jersey, P., Rudd, C. and Sills, J. 2010: Ancient British Coins, Aylsham, Norfolk: Chris Rudd

CIL Corpus Inscriptionum Latinarum

CSIR Corpus Signorum Imperii Romani

CSIR I.2 (Great Britain) Cunliffe, B. W. and Fulford, M. G. 1982. Bath and the Rest of Wessex, Oxford: Oxford University Press

CSIR I.4 (Great Britain) Keppie, L. J. F. and Arnold, B. J. 1984: Scotland, Oxford: Oxford University Press

CSIR I.7 (Great Britain) Henig, M. 1993: Roman Sculpture from the Cotswold Region with Devon and Cornwall, Oxford: Oxford University Press

CSIR I.10 (Great Britain) forthcoming: London and the South East of England, Oxford

CSIR IV.3 (Germany) Binsfeld, W., Goethert-Polaschek, K. and Schwinden, L. 1988. Katalog der römischen Steindenkmäler des Rheinischen Landesmuseums Trier, 1. Götter- und Weihedenkmäler, Mainz: Zabern

LIMC Lexicon Iconographicum Mythologiae Classicae VIII (1997), Zürich/Düsseldorf: Artemis

Ancient Sources

Cic. Div. Cicero, De Divinatione (trans. W. A. Falconer), 1938, London: W. Heinemann

Curt Q. Curtius Rufus, Historiae Alexandri Magni (trans. J. C. Rolfe), 1946, London: W. Heinemann

Pliny HN Pliny, Naturalis historia (trans. H. Rackham), 1940, London: W. Heinemann

Tac. Ann Tacitus, The Annals in Complete Works of Tacitus (trans. A. J. Church and W.

J. Brodribb), 1942, New York: Random House

Secondary Sources

Albarella, U. and PiRnie, T. 2008. A Review of Animal Bone evidence from Central England, http://archaeologicaldataservice.ac.uk/archives/view/animalbone_eh_2007

ANON. 1789. Appendix: Objects displayed to the Fellows on June 5th 1788, Archaeologia, 9, 370

ANON. 1849. Report on the meeting of Thursday, December 21st, 1848, Proceedings of the Society of Antiquaries of London (1st series), 1, 294-6

ARCE, J. et al. 1990. Los bronces romanos en España, Madrid: Ministerio de Cultura

BauchHenss, G. and NoelKe, P. 1981. Die Iupitersäulen in den germanischen Provinzen, Cologne, Beihefte der Bonner Jahrbücher, 41

BAXTER, I. 1993. An eagle, Haliaeetus albicilla (L), skull from Roman Leicester, England, Circaea, 10(1) for 1992, 31-7

BEECH, M. 2006. Animal remains: evidence of animal sacrifice, in Evans and Hodder 2006, $369-96$ 
BIDWell, P. 1979. The Legionary Bath-House and Basilica and Forum at Exeter, Exeter: Exeter Archaeol. Rep., 1

BIRD, J. 2007. Catalogue of Iron Age and Roman artefacts discovered before 1995, in R. Poulton, Farley Heath Roman temple, Surrey Archaeol. Collect., 93, 34-69

Boon, G. C. 1957. Roman Silchester, London: Max Parrish

Boon, G. C. 1974. Silchester. The Roman town of Calleva, Newton Abbott: David and Charles

Boon, G. C. 2000a. Other objects of copper alloy, in Fulford and Timby 2000, 338-57

Boon, G. C. 2000b. The statuary fragments: a review, in Fulford and Timby 2000, 587-8

Boube-Piccot, C. 1969. Les bronzes antique du Maroc, Rabat: Royaume du Maroc

Bramwell, D. 2006. Birds, in D. Hurst (ed.) Roman Droitwich: Dodderhill Fort, Bays Meadow Villa and Roadside Settlement, 220-1, York: CBA Res. Rep., 146

BRIGGS, D. N. 2013. Reading the images on Iron-Age coins: 6. Imperial eagles (Part 1), Chris Rudd List 130 (July 2013), 2-4.

BRIGGS, D. N. forthcoming. Reading the images on Iron-Age coins: 6. Imperial eagles (Part 2: Britain), Chris Rudd List.

Brown, L. 1976. British Birds of Prey, London: Collins

Chapman, J. 2000. Fragmentation in Archaeology. People, places and broken objects in the prehistory of South Eastern Europe, London: Routledge

Chapman, J. and Gaydarska, B. 2007. Parts and Wholes. Fragmentation in prehistoric context, Oxford: Oxbow Books

CoARELli, F. 2000. The Column of Trajan, Rome: Editore Colombo

Connell, B. and Davis, S. J. M. 1998. Animal bones from Roman Carlisle, Cumbria: The Lanes (2) excavation, 1978-1982. Draft EH Ancient Monuments Lab. Rep

Cowles, G. 1980. Bird bones, in D. M. Jones, Excavations at Billingsgate Buildings 'Triangle', Lower Thames Street, 1974, 163, London: London Middlesex Archaeol. Soc. Spec. Pap., 4

Cowles, G. 1993. Birds, in A. Woodward and P. Leach, The Uley Shrines. Excavation of a ritual complex on West Hill, Uley, Gloucestershire: 1977-9, 263-4, London: EH Archaeol. Rep., 17

Cramp, S. and Simmons, K. E. L. (eds) 1980. Handbook of the Birds of Europe, Middle East and North Africa, Vol 2: Hawks to bustards, Oxford: Oxford University Press

Creighton, J. 2000. Coins and Power in Late Iron Age Britain, Cambridge: Cambridge University Press

CROXFORD, B. 2003. Iconoclasm in Roman Britain?, Britannia, 34, 81-95

Cussans, J. E. and Bond, J. M. 2010. The animal bone, in I. Ferris, The Beautiful Rooms Are Empty. Excavations at Binchester Roman Fort, County Durham 1976-1981 and 19861991, 489-523, Durham: Durham County Council

DAVIS, S. J. M. 1997. Animal bones from the Roman site Redlands Farm, Stanwick, Northamptonshire, EH Ancient Monuments Lab. Rep. 106/97

DuRHAM, E. 2012. Depicting the gods: metal figurines in Roman Britain, Internet Archaeology, 31, http://intarch.ac.uk/journal/issue31/durham_index.html

ESPERANDIEU, E. 1907. Recueil général des bas-reliefs de la Gaule romaine, vol. 1, Paris: Imprimerie Nationale

Esperandieu, E. and Rolland, H. 1959. Bronzes Antique de la Seine-Maritime, Paris: Gallia Supplément, 13

Evans, C. and HodDer, I. 2006. Marshland Communities and Cultural Landscapes. The Haddenham Project. Vol. 2, Cambridge: McDonald Institute for Archaeological Research

FRERE, S. S. 1987. Roman Britain in 1986, Britannia, 18, 302-59 
Fulford, M. 2001. Links with the Past: Pervasive 'Ritual' Behaviour in Roman Britain, Britannia, 32, 199-218

Fulford, M. 2008. Nero and Britain: the palace of the client king at Calleva and imperial policy towards the province after Boudicca, Britannia, 39, 1-13

Fulford, M. and Timby, J. 2000. Late Iron Age and Roman Silchester. Excavations on the site of the forum-basilica 1977, 1980-86, London: Britannia Monogr. Ser., 15

Garcia y BELlido, A. 1966. Nuevos documentos militares de la Hispania Romana, Archivo Español de Arqueologia, 39, 24-40

GosDEn, C. 2005. What do objects want?, Journal of Archaeological Method and Theory, 12(3), 193-211

Gosden, C. and HiLl, J. D. 2008. Introduction: re-integrating 'Celtic' art, in D. Garrow, C. Gosden and J. D. Hill, Rethinking Celtic Art, 1-14, Oxford: Oxbow Books

GreEN, M. 1986. The Gods of the Celts, Gloucester: Alan Sutton

GREEN, M. 1989. Symbol and Image in Celtic Religious Art, London: Routledge

HAMILTON-DyeR, S. 1993. The animal bone, in J. D. Zienkiewicz, Excavations in the 'Scamnum Tribunorum' at Caerleon: the Legionary Museum Site 1983-5, Britannia, 24, 132-6

Hamilton-Dyer, S. 1999. Animal bones, in C. M. Hearne and V. Birbeck, A35 Tolpuddle to Puddletown Bypass DBFO, Dorset 1996-98, incorporating excavations at Tolpuddle Ball 1993, 188-202, Salisbury: Wessex Archaeol. Rep., 15.

HARMAN, M. 1993. The animal bone, in M. J. Darling and D. Gurney, Caister-on-Sea. Excavations by Charles Green, 1951-55, 223-38, Gressenhall: East Anglian Archaeol., 60

HaRman, M. 1994. Bird bones, in R. S. Leary, Excavations at the Romano-British Settlement at Pasture Lodge Farm, Long Bennington, Lincolnshire, 1975-77 by H.M. Wheeler, 52, Lincoln: Occ. Papers in Lincolnshire Hist. and Archaeol., 10

Harman, M. 1996. Birds, in J. May, Dragonby. Report on the excavations at an Iron Age and Romano-British settlement in North Lincolnshire, 163-4, Oxford: Oxbow Books.

Hemingway, S. 2000. Bronze sculpture, in R. Ling (ed.), Making Classical Art. Process and practice, 37-46, Stroud: Tempus.

HENIG, M. 1978. A Corpus of Roman Engraved Gemstones from British Sites, Oxford: Brit. Archaeol. Rep. Brit. Ser. 8 (2nd edn.)

Henig, M. 1990. The Content Family Collection of Ancient Cameos, Oxford: Ashmolean Museum

HenIG, M. 1995. The Art of Roman Britain, London: B. T. Batsford Ltd

Henig, M. and MunBy, J. 1973. Three bronze figurines, Oxoniensia, 38, 386-7

Holbrook, N. 1998. Shops in the western corner of Insula V, in N. Holbrook (ed.), The Roman Town Defences, Public Buildings and Shops, 217-30, Cirencester: Cirencester Excavations $\mathbf{V}$

HORN, H. G. 1972. Ein Römischer bronzeadler, Jahrbuch des Römisch-Germanischen Zentralmuseums Mainz, 19, 63-82

HoRN, R. 1938. Archäologische Funde in Italien, Tripolitanien, der Kyrenaika und Albanien vom Oktober 1937 bis Oktober 1938, Jahrbuch des Deutschen Archäologischen Instituts, 53, 616-743

JenkINS, G. K. 1972. Ancient Greek Coins, London: Barrie and Jenkins

JONES, J. M. 1986. A Dictionary of Ancient Greek Coins, London: Seaby

JOPE, E. M. 2000. Early Celtic Art in the British Isles, Oxford: Clarendon Press

JoYCE, J. G. nd. Journal of Excavations at Silchester, Museum of Reading

JoYCE, J. G. 1881. Third account of excavations at Silchester, Archaeologia, 46, 344-65 
Kaufmann-Heinimann, A. 1977. Die Römischen Bronzen der Schweiz. I Augst und das Gebiet der Colonia Augusta Raurica, Mainz: Zabern

KIRK, J. R. 1949. Bronzes from Woodeaton, Oxon, Oxoniensia, 14, 1-45

KLEINER, D. E. E. 1992. Roman Sculpture, New Haven: Yale University Press

LeIBundgut, A. 1976. Die Römischen Bronzen der Schweiz. II Avenches, Mainz: Zabern

LEIBUNDGUT, A. 1980. Die Römischen Bronzen der Schweiz. III Westschweiz, Bern und Wallis, Mainz: Zabern

LuFF, R. 1985. The fauna, in R. Niblett, Sheepen: an early Roman industrial site at Camulodunum, 143-9, London: Coun. Brit. Archaeol. Res. Rep., 57

Luzón Nogué, J. M. and SÁnchez-PAlencia Ramos, F. J. 1980. Monte Cido o Torre Cabreira, Excavaciones Arqueologicos en España, 110, 35-6

Matthews, C. L. 1981. A Romano-British inhumation cemetery at Dunstable, Bedfordshire Archaeol. J., 15, 1-73

Mattingly, H. 1923. A Catalogue of Coins of the Roman Empire in the British Museum, Vol. 1 Augustus to Vitellius, London: Longman

Meddens, B. 2002. Animal bones from Bainesse (Site 46), in P. R. Wilson, Cataractonium: Roman Catterick and its Hinterland. Excavations and Research, 1958-1997. Part II, 419-25, York: Counc. Brit. Archaeol. Res. Rep., 129

Megow, K. 1987. Kameen von Augustus bis Alexander Severus, Berlin: de Gruyter

MulKeEn, S. and O'CONNOR, T. P. 1997. Raptors in towns: towards an ecological model, International J. of Osteoarchaeol., 7(4), 440-9

NIEMEYER, H. G. 1968. Studien zur statuarischen darstellung der Römischen Kaiser, Berlin: Monumenta artis romanae, 7

O’Connor, T. P. 1993. Bird bones, in P. J. Casey, J. L. Davies and J. Evans, Excavations at Segontium (Caernarfon) Roman Fort, 1975-1979, 119, London: Counc. Brit. Archaeol. Res. Rep., 90

Pannuti, U. 1983. Catalogo della Collezione Glittica vol. 1, Rome: Istituto poligrafico e zecca dello stato

PARKER, A. J. 1988. The birds of Roman Britain, Oxford J. Archaeol., 7(2), 197-226

Richter, G. M. A. 1956. Greek and Roman Antiquities in the Dumbarton Oaks Collection, Cambridge: Harvard University Press

RIXSON, D. 1978. Animal bones, in G. Marsh, 8 Union Street, Southwark Excavations 19721974, 231-2, London: London Middlesex Archaeol. Soc

RostovtzeFF, M. 1923. Commodus-Hercules in Britain, J. Roman Stud., 13, 91-109

SERJEANTSON, D. 2006. Animal remains, in Evans and Hodder 2006, 213-48

SERJEANTSON, D. 2009: Birds, Cambridge: Cambridge University Press

SERJEAnTSOn, D. and MorRIS, J. 2011. Ravens and crows in Iron Age and Roman Britain, Oxford J. Archaeol., 30(1), 85-107

SiLlitoe, P. 1988. From head-dresses to head-messages: the art of self-decoration in the highlands of Papua New Guinea, Man. New series, 23(2), 298-318

SPEIDEL, M. P. 1976. Eagle-bearer and trumpeter, Bonner Jahrbucher, 176, 123-63

STALLIBRASS, S. 1996. Animal bones, in R. Jackson, Excavations at Stonea Grange, in R. P. Jackson and T. W. Potter (eds), Excavations at Stonea, Cambridgeshire, 1980-85, 587-612, London: British Museum

Stoll, O. 2007. The religions of the armies, in P. Erdkamp (ed.), A Companion to the Roman Army, 451-76, Oxford: Blackwell

SutClifF, R. 1954. The Eagle of the Ninth, London: Oxford University Press

SutCLIFF, R. 1957. The Silver Branch (reprinted 1980), London: Puffin

TÖPFER, K. M. 2011. Signa Militaria. Die römischen Feldzeichen in der Republik und im Prinzipat, Mainz: Monographien des RGZM Band, 91 
TOYNBEE, J. M. C. 1964. Art in Britain Under the Romans, Oxford: Clarendon Press

ToYnBEe, J. M. C. 1973. Animals in Roman Art and Life, London: Thames and Hudson

TOYNBEE, J. M. C. 1979. A note on the sculpted torso of a bird, in Bidwell 1979, 130-2

TsCHudin, P. 1962. Ein Bronze-Adler aus Munzach, Ur-Schweiz. La Suisse Primitive, 26(4), 67-71

VAN ARSDEll, R. D. 1989. Celtic Coinage of Britain, London: Spink

Walters, H. B. 1899. Catalogue of the Bronzes, Greek, Roman, and Etruscan, in the Department of Greek and Roman Antiquities, British Museum, London: British Museum

WiLliams, D. F. 2002. Purbeck marble in Roman and medieval Britain, in D. A. Hinton (ed.), Purbeck Papers, 126-31, Oxford: University of Southampton Dept. of Archaeol. Monogr., 4

WoOLF, G. 2001. Representation as cult: the case of the Jupiter columns, in W. Spickermann, H. Cancik and J. Rüpke (eds), Religion in den germanischen Provinzen Roms, 117-34, Tübingen: Mohr Siebeck

YALDEN, D. W. 2007. The older history of the white-tailed eagle in Britain, British Birds, 100, 471-80

Yalden, D. W. and Albarella, U. 2009. The History of British Birds, Oxford: Oxford University Press 